\title{
Effects of Imperata cylindrica on Anti-hyperlipidemia: A Review
}

\author{
Maryati Maryati $^{1}$ (D), Ike Widyaningrum ${ }^{1}$ (D), Erna Sulistyowati 1,*(i) \\ 1 Medical Program, Faculty of Medicine, University of Islam Malang, Indonesia \\ * Correspondence: dr_erna@unisma.ac.id (E.S.);
}

Scopus Author ID 57194460735

Received: 2.10.2021; Revised: 15.11.2021; Accepted: 17.11.2021; Published: 9.12.2021

\begin{abstract}
Imperata cylindrica is a well-known species of perennial rhizomatous grass native to tropical South East Asia, which possesses extensive medicinal value. It has major constituents such as saponin, flavonoid, phenols, and glycosides, efficacious as an anti-hyperlipidemia. Studies of pharmacological activities of I. cylindrica, a nutritious, medicinal herb, showed that it could cause blood lipid levels to be reduced. This systematic review article was designed to determine the existing studies related to the efficacy of I. cylindrica to lower blood lipid levels. PubMed and Scopus databases were used to search for suitable keywords such as Imperata cylindrica, cogongrass, hypolipidemic, triglyceride, cholesterol, low-density lipoprotein (LDL), and very-low-density lipoprotein (VLDL). Based on provided protocol, in this systematic review, we extracted the data and evaluated the quality of articles by two reviewers. (4) Results 73 articles were the search results and based on the inclusions and exclusions criteria, 8 articles were included in the final review. These studies demonstrated that two active compounds of $I$. cylindrica: flavonoids and saponins, were beneficial to reduce blood lipid levels. However, further clinical studies are urgently required to provide adequate evidence on the use application of I. cylindrica in medicinal properties.
\end{abstract}

Keywords: Imperata cylindrica; hyperlipidemia; cholesterol; triglyceride; LDL.

(C) 2021 by the authors. This article is an open-access article distributed under the terms and conditions of the Creative Commons Attribution (CC BY) license (https://creativecommons.org/licenses/by/4.0/).

\section{Introduction}

The prevalence of hyperlipidemia and subsequent coronary artery disease is high among developed countries as well as in regions with lower income levels [1,2]. As the World Health Organization (WHO) reported, cardiovascular diseases are the most common cause of death in the world. However, changing the lifestyle and medication in these diseases could attenuate it $[3,4]$. Hyperlipidemia is a lipid metabolic disorder characterized by elevated lipid levels in the blood, including total cholesterol, triglycerides, and LDL, commonly called hypercholesterolemia or hypertriglyceridemia [5,6].

Hyperlipidemia is a chronic disease that requires treatment in the long term $[7,8]$. The clinical benefits provided from pharmacological treatment in hyperlipidemia should not lessen our attention to reduce the side effects caused by long-time treatment of anti hyperlipidemia in patients [1,9]. Currently, herb-based traditional medicine has been widely used, and WHO initiated to development of herbal-based medicine as a potential therapeutic strategy [10], including treatment for hyperlipidemia [11]. Cogon grass (Imperata cylindrica), a member of the Gramineae family, is found all over the place but is often considered useless and treated as a weed. However, this plant is extensively utilized in traditional medicine, particularly Asia 
[12]. Imperata cylidrica is known to have functions to reduce plasma lipid concentrations [12$14]$.

There vast amount of kinds of literature that depicts that Imperata cylindrica possess major phytochemical constituents such as saponins, flavonoids, glycosides, phenols, and coumarins [15]. The rhizomes of I. cylindrica had been identified as containing many compounds with biological properties such as arundoin, cylindrin, cylindol, graminones, cylindrene, imperanene, and fernenol [16]. Scientific pharmacology research on I. cylindrica have shown that several substances from it exhibit an extensive range of biological activities, for instance: hemostasis, improvement of urination [17], analgesic, anti-inflammatory and antipyretic [18], enhancement of the immune system [15,16], antibacterial [19], anticancer [20], etc.

In this review, we designed to systematically demonstrate the advances achieved in anti-hyperlipidemia of Imperata cylindrica related studies in recent decades, along with the mechanisms. Furthermore, we provided a systematic overview of the available information of I. cylindrica, including in vivo studies and clinical trials.

\section{Materials and Methods}

The databases used for data search were PubMed and Google scholar to examine the proper keywords such as Imperata cylindrica OR cogongrass AND hypolipidemic; Imperata cylindrica OR cogongrass AND triglyceride; Imperata cylindrica OR cogongrass AND cholesterol; Imperata cylindrica OR cogongrass AND LDL OR VLDL.

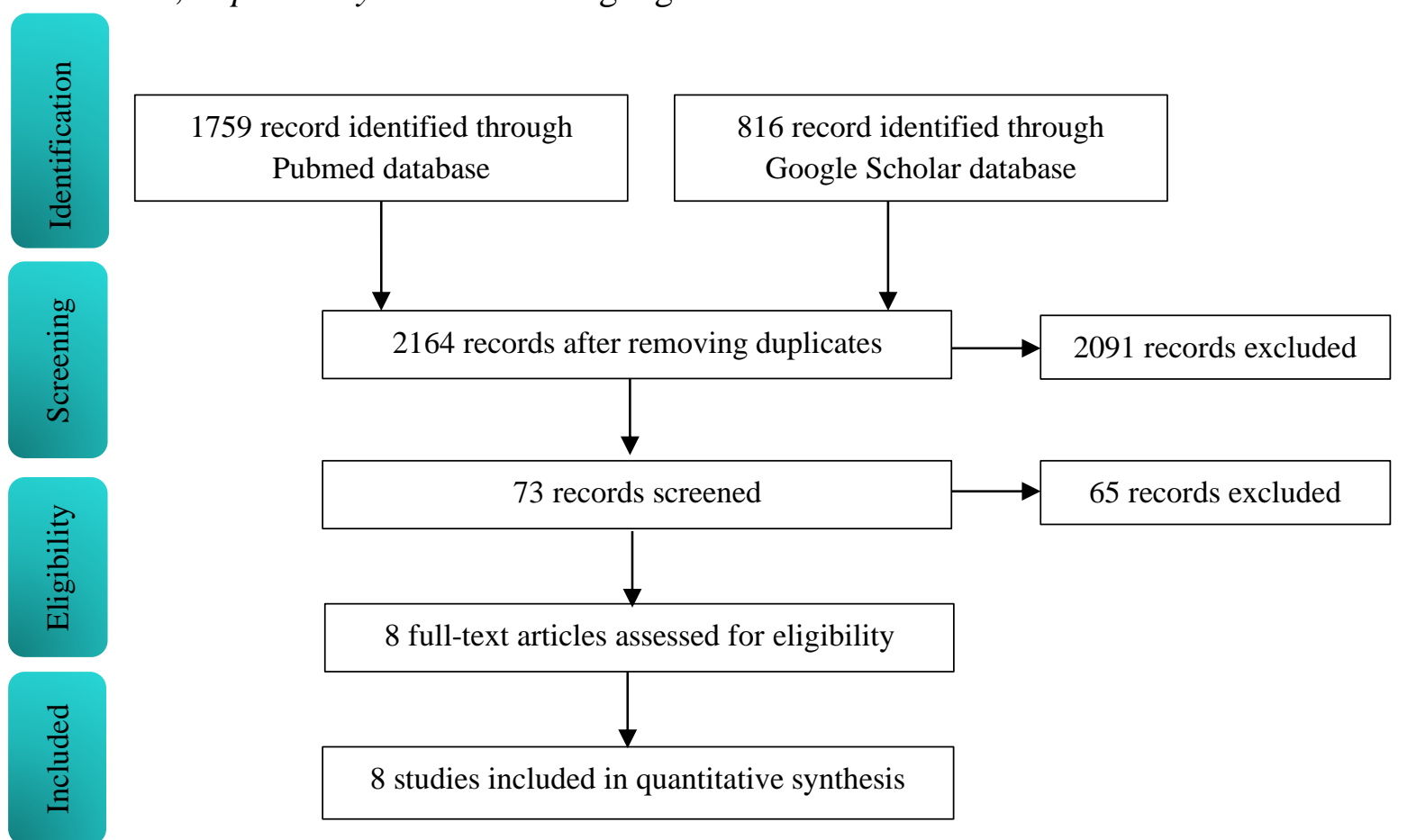

Figure 1. Flow diagram showing the number of records identified, screened, extracted, and included in the final analysis.

All inclusion criteria were defined in the studies we reviewed in this article. The categories of research were included clinical trials and in vivo studies that evaluated the potential of anti hyperlipidemia of I. cylindrica. However, the requirements criteria for articles were the international journal articles with the United Nations (UN) language, journal articles with Bahasa (Indonesian language), publication period from 2011 to 2021, and original 
research articles. The articles with only provided abstract sections were excluded from the review. Some articles were omitted because they were about the non-medicinal term of use. Two reviewers independently extracted the data from articles to fill in table items. Subsequently, the bias assessment was carried out for clinical trials and in vivo studies. According to Ma (2020), for clinical trials, we provided three bias assessment scales: Jadad scale [21], Newcast Ottawa Scale (NOS) [22], and Cochrane Risk of Bias Tool [23,24]. The determination of journal validity was using recommended viewed through the parameters of the Jadad scale (a score of $\geq 3$ were categorized as high-quality studies), NOS scale (a score of $\geq 7$ ), and Cochrane Risk of Bias Tool by checking at the provisions of low bias risk (a score of $\geq 3$ ), high bias risk (a score of $\leq 2$ ), and unclear (a score of $\leq 4$ ). The appropriate requirement for validity was when two different scales showed high scores. However, bias assessment for the in vivo studies was using recommended Cochrane Risk of Bias Tool [23,25]. The journal article was extracted and considered valid when it provided author's name, year of publication, type of research, the sample, hyperlipidemia stimulation type, I. cylindrica derivative products used, a certain dosage of I. cylindrica, parameters measured, and the outcomes.

\section{Results and Discussion}

\subsection{Study selection.}

We initially retrieved a total of 2575 potentially eligible articles in the database search; 1759 were found in Pubmed, and 816 were taken from Google scholar. 411 articles were excluded because of being duplicates. 2164 articles met the exclusion criteria. 2091 articles were also excluded because they were review articles or part of the book, and some did not match the topic based on the abstract and title. 73 articles were then screened for the inclusion criteria, and 65 articles were removed because of their study about the effect of I. cylindrica on other diseases. Therefore, 8 articles were included in the final analysis after assessing bias (see Figure 1).

\begin{tabular}{|c|c|c|c|c|c|c|c|c|c|c|}
\hline No & Author & Year & \begin{tabular}{|c|} 
Random \\
sequence \\
generation
\end{tabular} & $\begin{array}{c}\text { Allocation } \\
\text { concealment }\end{array}$ & $\begin{array}{c}\text { Blinding of the } \\
\text { participant and } \\
\text { personal }\end{array}$ & \begin{tabular}{|} 
Blinding of \\
outcome \\
assessment
\end{tabular} & $\begin{array}{c}\begin{array}{c}\text { Incomplete } \\
\text { outcome } \\
\text { data }\end{array} \\
\end{array}$ & $\begin{array}{l}\text { Selective } \\
\text { reporting }\end{array}$ & $\begin{array}{c}\text { Other } \\
\text { bias }\end{array}$ & Conclusion \\
\hline 1. & $\begin{array}{l}\text { Anggraeni et } \\
\text { al. }[26]\end{array}$ & 2017 & $x$ & $\sqrt{ }$ & $?$ & $?$ & $\sqrt{ }$ & $\sqrt{ }$ & $\sqrt{ }$ & Good \\
\hline 2. & $\begin{array}{l}\text { Robianto et } \\
\text { al. [27] }\end{array}$ & 2019 & $\sqrt{ }$ & $\sqrt{ }$ & $?$ & $\sqrt{ }$ & $\sqrt{ }$ & $\sqrt{ }$ & $\sqrt{ }$ & Good \\
\hline 3. & \begin{tabular}{|l|} 
Khaerunnisa \\
et al. $[12]$
\end{tabular} & 2020 & $\sqrt{ }$ & $?$ & $?$ & $\sqrt{ }$ & $\sqrt{ }$ & $\sqrt{ }$ & $\sqrt{ }$ & Good \\
\hline 4. & $\begin{array}{l}\text { Khaerunnisa } \\
\text { et al. }[28]\end{array}$ & 2014 & $\sqrt{ }$ & $x$ & $?$ & $\sqrt{ }$ & $x$ & $\sqrt{ }$ & $\sqrt{ }$ & Good \\
\hline 5. & \begin{tabular}{|l|} 
Hsieh et al. \\
{$[29]$}
\end{tabular} & 2014 & $\sqrt{ }$ & $x$ & $?$ & $\sqrt{ }$ & $\sqrt{ }$ & $\sqrt{ }$ & $\sqrt{ }$ & Good \\
\hline 6. & $\begin{array}{l}\text { Ihsan et al. } \\
{[30]}\end{array}$ & 2018 & $\sqrt{ }$ & $\sqrt{ }$ & $?$ & $\sqrt{ }$ & $\sqrt{ }$ & $?$ & $?$ & Good \\
\hline 7. & $\begin{array}{l}\text { Jue et al. } \\
{[13]}\end{array}$ & 2012 & $x$ & $\sqrt{ }$ & $?$ & $\sqrt{ }$ & $x$ & $\sqrt{ }$ & $\sqrt{ }$ & Good \\
\hline 8. & $\begin{array}{l}\text { Cho et al. } \\
{[31]}\end{array}$ & 2017 & $\sqrt{ }$ & $\sqrt{ }$ & $\sqrt{ }$ & $\sqrt{ }$ & $\sqrt{ }$ & $\sqrt{ }$ & $\sqrt{ }$ & Good \\
\hline
\end{tabular}

Note: $\sqrt{ }$ : Low-Risk Bias,; $\times$ : High-Risk Bias,; ?: Unclear

\subsection{Article bias analysis.}

According to the bias analysis, as shown in Table 1, we evaluated the Jadad scale, NOS, and Cochrane risk of bias tool, which were applied for clinical trials. However, the in vivo 
studies were using only the Cochrane Risk of Bias Tool. Based on the Cochrane Risk of Bias Tool, the study was determined for risk parameters including blinding of outcome assessment (detection bias), the highest risk of bias was detected in allocation concealment (selection bias), and incomplete outcome data (attrition bias). The incomplete parameters were found in the participants and personnel blinding (performance bias) because some articles provided inadequate information about the investigators who conducted the research (see Figure 2). Despite this, the in vivo studies provided higher scores than clinical trials as it was aforementioned that these meant fewer systematic errors found in the research process. Clinical trials were categorized as valid when according to the Jadad scale, 5 (maximum of 5), NOS scale was 8 (maximum of 13). As presented in Table 2, we retrieved only one clinical trial that was considered to have no systematic errors in the research process.

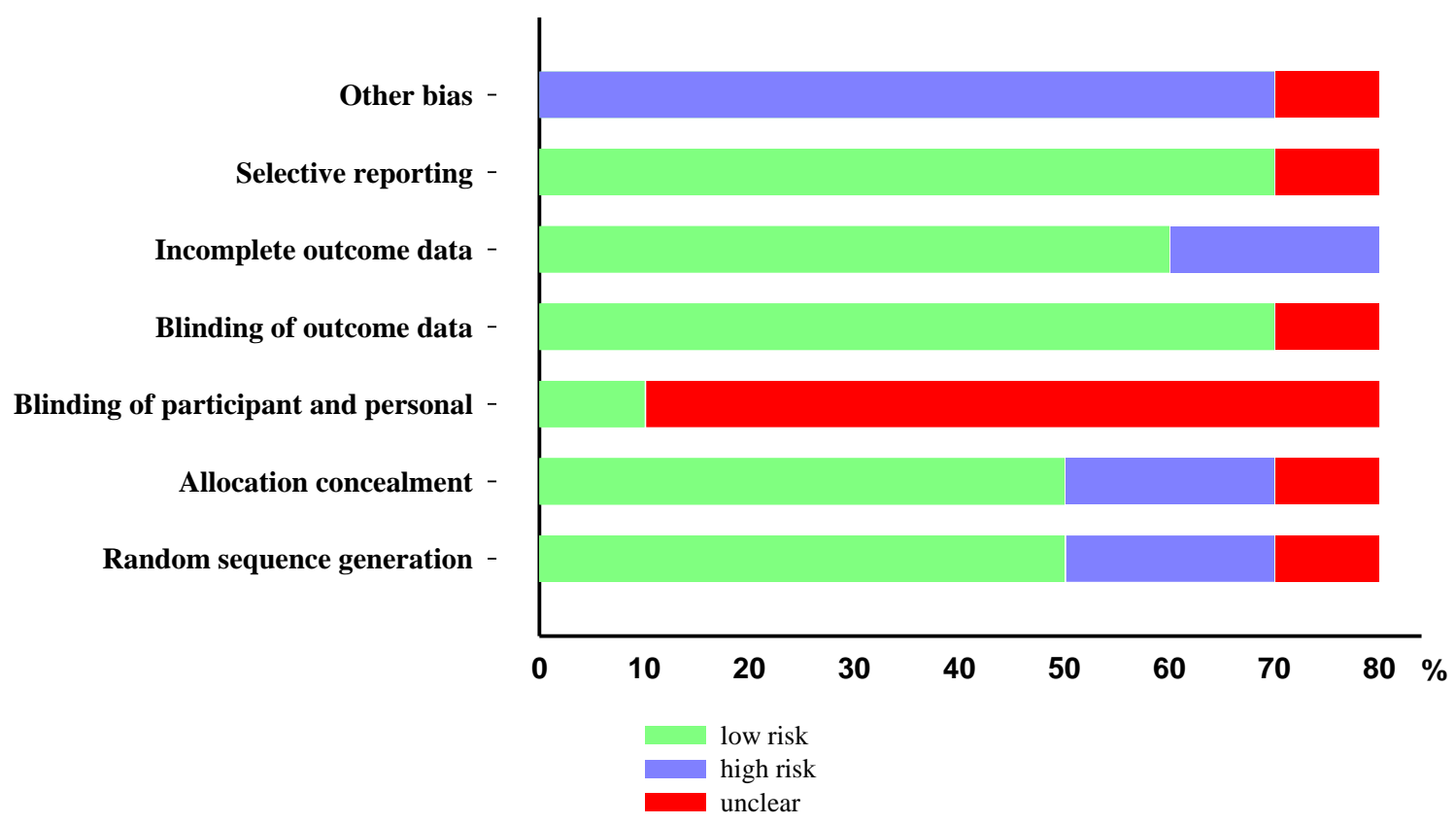

Figure 2. Graph of bias analysis assessment results using Cochrane parameters.

Table 2. The validity results of the clinical trial.

\begin{tabular}{c|c|c|c|c|c|c} 
No & Author & Year & NOS Scale & Jadad scale & Cochrane & Conclusion \\
\hline 1. & Cho., et al $[31]$ & 2017 & 8 (Good) & 5 (Good) & Good & Valid
\end{tabular}

Note: Journal validity results using three bias assessment scales

\subsection{Potential anti-hyperlipidemia Imperata cylindrica.}

Table 3 shows the summary results of a systematic literature review analysis about the potential efficacy of Imperata cylindrica as an anti-hyperlipidemia through in vivo studies. However, Table 4 demonstrated the result of a systematic literature review analysis in the clinical trial. Several studies indicated that the root part (rhizome) [12,26,27]. The other segment was leaves [29] and the whole piece of the plant [30]. Moreover, several studies used certain preparations of plants such as root's polysaccharides [13] and powder [28,31].

The outcome of studies was identified that three in vivo studies showed a decrease in serum levels, including total cholesterol, triglycerides, and LDL. Most in vivo studies demonstrated a reduction in total cholesterol levels [13,26,27,29,31]. Two studies showed the decrease in TG level [29, 31], and three studies provided the reduced level of LDL [12,30,31]

The experimental dose of I. cylindrica administered in the in vivo studies varied from a range of $75 \mathrm{mg} / \mathrm{kg} \mathrm{BW}$ to $500 \mathrm{mg} / \mathrm{kg} \mathrm{BW}$. While in a clinical trial, the dose was administered 
at $2400 \mathrm{mg} / \mathrm{day}$. Of 8 articles retrieved, 6 articles showed that their in vivo studies led to lower lipid levels in the blood and one clinical trial we reviewed [12,13,26,28-30]. Aside from that, an in vivo study showed a less significant effect [27].

Table 3. The validity results of the in vivo studies.

\begin{tabular}{|c|c|c|c|c|c|c|c|c|c|c|c|}
\hline No. & Author & Year & $\begin{array}{c}\text { Type } \\
\text { research }\end{array}$ & Sample & inducer & $\begin{array}{l}\text { Derivative } \\
\text { products } I . \\
\text { cylindrica }\end{array}$ & Dosing & $\begin{array}{c}\text { Measured } \\
\text { parameter } \\
\text { S }\end{array}$ & \multicolumn{3}{|c|}{ Outcome } \\
\hline & & & & & & & & & TC & TG & LDL \\
\hline 1. & $\begin{array}{l}\text { Anggraeni } \\
\text { et al. }[26]\end{array}$ & 2017 & in vivo & $\begin{array}{c}\text { Male rat age 8- } \\
10 \text { mnggu (Mus } \\
\text { muscularis) }\end{array}$ & $\begin{array}{l}\text { Administration } \\
\text { of intragastric } \\
\text { olive oil }\end{array}$ & Root extract & $\begin{array}{c}90 \mathrm{mg} / \mathrm{kg} \\
\mathrm{BW} \text { and } \\
115 / \mathrm{kg} \mathrm{BW}\end{array}$ & \begin{tabular}{|c|} 
Total \\
Serum \\
Cholesterol
\end{tabular} & $\downarrow$ & ND & ND \\
\hline 2. & $\begin{array}{c}\text { Robianto et } \\
\text { al. }[27]\end{array}$ & 2019 & in vivo & \begin{tabular}{|c|}
$\begin{array}{c}21 \text { Female rats } \\
\text { aged } 8-12 \\
\text { weeks }\end{array}$ \\
\end{tabular} & $\begin{array}{c}\text { Administration } \\
\text { of water ad } \\
\text { libitum } \\
\end{array}$ & Root extract & $\begin{array}{l}90 \text { and } 115 \\
\mathrm{mg} / \mathrm{kg} \mathrm{BW} \\
\text { per day }\end{array}$ & $\begin{array}{l}\text { Total serum } \\
\text { cholesterol }\end{array}$ & $\uparrow$ & ND & ND \\
\hline 3. & $\begin{array}{c}\text { Siti } \\
\text { Khaerunnis } \\
\text { et al. }[12]\end{array}$ & 2020 & in vivo & $\begin{array}{c}\text { Male Wistar } \\
\text { rats aged 2-3 } \\
\text { months, weight } \\
180-200 \mathrm{mg}\end{array}$ & $\begin{array}{c}\text { Giving ad } \\
\text { libitum access to } \\
\text { food and } \\
\text { beverages }\end{array}$ & Root extract & $\begin{array}{c}75 \mathrm{mg} / \mathrm{kg} \\
\mathrm{BW}\end{array}$ & $\begin{array}{c}\text { Total } \\
\text { Cholesterol, } \\
\text { LDL }\end{array}$ & ND & ND & $\downarrow$ \\
\hline 4. & $\begin{array}{c}\text { St. } \\
\text { Khaerunnis } \\
\text { et al. }[28]\end{array}$ & 2018 & in vivo & $\begin{array}{l}28 \text { male Wistar } \\
\text { rats aged } 3 \\
\text { months, } \\
\text { weighing } \\
180-200 \text { grams. }\end{array}$ & High-fat diet & Dry powder & $\begin{array}{c}75 \mathrm{mg} / \mathrm{kg} \\
\text { bb ethanol } \\
\text { extract and } \\
\text { acetate } \\
\text { fraction } \\
\end{array}$ & $\begin{array}{l}\text { Enzyme } \\
\text { activity of } \\
\text { SOD }\end{array}$ & $\downarrow$ & ND & ND \\
\hline 5. & $\begin{array}{l}\text { Hsieh et al. } \\
\text { [29] }\end{array}$ & 2014 & in vivo & $\begin{array}{c}\text { Male Golden } \\
\text { Syrian hamster, } \\
\text { weight } 260-270 \\
\mathrm{~g} \\
\end{array}$ & PME diet & Leaf extract & ND & \begin{tabular}{|c|} 
Total \\
cholesterol, \\
TG
\end{tabular} & $\downarrow$ & $\downarrow$ & ND \\
\hline 6. & $\begin{array}{c}\text { Ihsan et al. } \\
\text { [30] }\end{array}$ & 2018 & in vivo & $\begin{array}{l}24 \text { Male mice } \\
\text { (Mus musculus } \\
\text { L.) with an } \\
\text { average weight } \\
\text { of } 30.6 \text { grams } \\
\text { and an average } \\
\text { age of } 35 \text { days }\end{array}$ & $\begin{array}{l}\text { High-fat diet and } \\
\text { administration of } \\
\text { propylthiouracil } \\
\text { drugs (PTU) }\end{array}$ & $\begin{array}{c}\text { Whole plant } \\
\text { parts }\end{array}$ & $\begin{array}{l}250 \mathrm{ml} / \mathrm{kg} \\
\mathrm{BB} \text { and } \\
\text { dose } 500 \\
\mathrm{ml} / \mathrm{kg} \mathrm{BB}\end{array}$ & LDL levels & ND & ND & $\downarrow$ \\
\hline 7. & $\begin{array}{c}\text { Jue } e t \text { al. } \\
\text { [13] }\end{array}$ & 2012 & in vivo & Male rat & $\begin{array}{c}\text { Administration } \\
\text { of streptozotocin } \\
\text { (STZ): a mouse } \\
\text { model of } \\
\text { diabetes }\end{array}$ & $\begin{array}{c}\text { Polysaccharid } \\
\text { es Roots } \\
\text { reeds }\end{array}$ & $\begin{array}{l}\text { Low doses } \\
\text { and high } \\
\text { doses }\end{array}$ & $\begin{array}{l}\text { TC, TG, } \\
\text { LDL-C }\end{array}$ & $\downarrow$ & $\downarrow$ & ND \\
\hline
\end{tabular}

Note: ND: No Data; $\downarrow$ Significant Decreased; $\uparrow$ Significantly Increased

Tabel 4. The valid results of clinical trials.

\begin{tabular}{|c|c|c|c|c|c|c|c|c|c|c|c|c|c|}
\hline \multirow[b]{2}{*}{ No. } & \multirow[b]{2}{*}{ Author } & \multirow[b]{2}{*}{ Year } & \multirow[b]{2}{*}{$\begin{array}{l}\text { Types of } \\
\text { research }\end{array}$} & \multirow[b]{2}{*}{$\begin{array}{c}\text { Research } \\
\text { design }\end{array}$} & \multirow[b]{2}{*}{ Sample } & \multirow[b]{2}{*}{$\begin{array}{c}\text { Derivative products of } \\
\text { I.cylindrica }\end{array}$} & \multirow[b]{2}{*}{ Dose } & \multirow{2}{*}{$\left|\begin{array}{c}\text { Lengt } \\
\text { h of } \\
\text { use }\end{array}\right|$} & \multicolumn{2}{|c|}{ Research group } & \multicolumn{3}{|c|}{ Outcome } \\
\hline & & & & & & & & & \begin{tabular}{|l|} 
Contro \\
I group
\end{tabular} & $\begin{array}{c}\text { Treatment } \\
\text { group }\end{array}$ & TC & TG & LDL \\
\hline 1 & $\begin{array}{l}\text { Cho et } \\
\text { al. [31] }\end{array}$ & 2017 & $\begin{array}{c}\text { Clinical } \\
\text { trial }\end{array}$ & $\begin{array}{l}\text { Case } \\
\text { control }\end{array}$ & $\begin{array}{c}60 \\
\text { participants }\end{array}$ & $\begin{array}{c}\text { Tablets YY-312 (herbal } \\
\text { extract powder, } I . \\
\text { cylindrica } \text { Beauvois, } \\
\text { Citrus Markovich, } \\
\text { and Evodia officinalis } \\
\text { comparison 5:2:3) }\end{array}$ & $\begin{array}{c}2400 \\
\mathrm{mg} / \text { day }\end{array}$ & $\begin{array}{c}12 \\
\text { weeks }\end{array}$ & $\begin{array}{l}\text { Placeb } \\
\text { o group } \\
\text { control }\end{array}$ & $\begin{array}{l}\text { Patients } \\
\text { with a BMI } \\
\text { of } 25.0-29.9 \\
\mathrm{~kg} / \mathrm{m} 2 \text { with } \\
\text { YY-312 }\end{array}$ & $\downarrow$ & $\downarrow$ & $\downarrow$ \\
\hline
\end{tabular}

Note: $\downarrow$ : Significant decreased,; Total Cholesterol (TC), Triglyceride (TG), Low-Density Lipoprotein (LDL)

\subsection{Effects of Imperata cylindrica in intestinal lipid absorption.}

To date, 72 compounds from I. cylindrica were identified; among them, flavonoids and saponins are the main compositions. The potential bioactive saponins may contribute either directly or indirectly to inhibit lipid absorption in the intestinal tissue. Saponins exhibit binding formation between lipids and bile acids to generate a strong field complex that prevents the process of lipid emulsification. Saponins may block the formation of micelles with lipids during digestion in the small intestine; thus, lipids absorption availability into enterocytes was reduced. Saponins are also inhibited by bile acid and lipid reabsorption due to the formation of 
large mixed micelles. This formation is water-insoluble, so it can not be absorbed by the intestines and then excretes in the feces [32]. Inhibition of reabsorption of bile acids from the intestine stimulates the metabolism of cholesterol in the liver then converts it into bile acids [33].

In addition, saponins inhibit the activity of pancreatic lipase enzymes, thus suppressing the lipid degradation process [34,35]. It leads to a reduced lipid absorption process in the intestinal. Ali et al. (2019) demonstrated this pathway through in vivo study using an albino Wistar rat administered with a high-fat diet and saponins taken from the combination of Trigonella foenum-graecum seeds, Asparagus officinalis shoots, Glycyrrhiza glabra, and Saponaria officinalis rhizomes. They found that the administration of saponins from this combination significantly caused in lowering of serum triglyceride levels compared to the control $[34,36]$.

\subsection{Effects of Imperata cylindrica in the induction of lipoprotein lipase activity.}

Imperata cylindrica contains flavonoids that possess biological activities, mainly causing the increase of lipoprotein lipase enzyme activity [37]. Lipoprotein lipase is abundant in adipose tissue and skeletal muscle's capillaries and plays a role in the triglycerides hydrolysis process into free fatty acids and glycerol $[38,39]$. In muscles, free fatty acids are provided for energy formation and an energy reservoir in adipose tissue. It leads to lower blood triglyceride levels. Hil et al. (2012) demonstrated a similar pathway through in vitro study with the administration of flavonoids quercetin, catechin, naringenin, luteolin, kaempferol, and genistein. Their research found that administering quercetin, kaempferol, and catechins to culture media can significantly reduce the free fatty acid (FFA) level. Flavonoids luteolin also caused significantly reduced triglycerides to level through in vitro study [40]. Furthermore, Mazumder et al. (2021) demonstrated a similar pathway through in vivo study with the administration of flavonoids from the combination of Azadirachta indica A. Juss., Trigonella foenum-graecum L., Allium sativum L., and Zingiber officinale. Their research found that the administration of this combination significantly caused a reduction in triglycerides level through in vivo study [41].

\subsection{Effect of Imperata cylindrica in the SREBP-1c and PPAR- $\alpha$ gene induction pathways.}

The anti-hyperlipidemic activity of Imperata cylindrica is due to the presence of flavonoids I. cylindrica which can affect the coding genes SREBP-1 and PPAR- $\alpha$. At the physiological state, SREBP-1c and SREBP-2 genes are synthesized in the liver tissue. SREBP1c supports the fatty acid biosynthetic pathway, and SREBP-2 maintains cholesterol synthesis [42]. SREBP-2-gen responsive in cholesterol biosynthetic pathways include the enzyme HMGCoA synthase, HMG-CoA reductase, farnesyl diphosphate synthase, and squalene synthase which play a role in the process of cholesterol synthesis [42]. Other SREBP-1c target genes encode enzymes in the liver's synthesis of triglycerides and phospholipids [42]. Induction in the SREBP-1c gene can increase the formation of triglycerides and then be stored in the liver tissue. Thus, the activity of SREBP-2 leads to a decrease in cholesterol synthesis [42].

The transcription activity of the SREBP-1 gene may also be enhanced by the activation of the target protein PPAR- $\alpha$. PPAR- $\alpha$ is known to function as a target protein that regulates lipoprotein metabolism and controls directly or indirectly lipogenic pathways in the liver tissue. Lipogenesis is a metabolic pathway that allows the synthesis of fatty acids when dietary lipids are abundant. PPAR- $\alpha$ agonists can increase the transcription activity of the SREBP-1c gene 
by interacting with the promoter elements of SREBP-1c [43]. Similarly, Mulvihil et al. (2009) demonstrated the effects of flavonoid naringenin administration through in vivo study. Their findings showed that administering flavonoid naringenin increased the expression of the SREBP-1 liver gene by 3.9 times compared to the controls [44]. In addition, they found that flavonoids significantly increased PPAR- $\alpha$ regulation by $30 \%$ compared to controls [44].

\subsection{Effects of Imperata cylindrica on 3-hydroxy-3-methyl-glutaryl-CoA Reductase inhibition.}

The activity of I. cylindrica as anti hyperlipidemia is partly due to a decrease in the activity of 3-hydroxy-3-methyl-glutaryl-Coenzyme A (HMG-CoA) reductase, which is likely due to the presence of flavonoid content in I. cylindrica [45]. Flavonoids content has hydrophobic characteristics that allow it to bind HMG-CoA reductase and cause decreasing its activity [46]. HMG-CoA reductase is one of the enzymes that play a role in the process of cholesterol synthesis [46]. The formation of cholesterol begins from the alteration of Acetyl CoA to HMG-CoA, which provides HMG-CoA synthase. HMG-CoA then converts into mevalonate acid with the role of HMG-CoA reductase to form cholesterol [46]. Kwon et al. (2010) showed similar effects on the administration of flavonoid bud $R$. damascena through in vivo study. They found that giving flavonoid R.damascena significantly inhibited the activity of the HMG-CoA reductase enzyme [47]. Decreased activity of HMG-CoA reductase can suppress the process of cholesterol formation, thus causing a decrease in cholesterol synthesis [46]. Bao et al. (2016) demonstrated a related pathway using in vivo study with flavonoid Lomagonium rotatum administration. Their results demonstrated that administering the flavonoid Lomagonium rotatum significantly lowered the total cholesterol level compared to the controls [48]. Further, Halim et al. (2021) demonstrated a related pathway using in vivo study with flavonoid Carica papaya Linn administration. Their results demonstrated that administering the flavonoid of Carica papaya Linn significantly lowered total cholesterol levels compared to the controls [49].

Simultaneously, cholesterol and other lipid components are formed in the liver and then released into the blood circulation in VLDL form [2]. Afterward, VLDL activates lipoprotein lipase located in the capillaries causing VLDL triglyceride hydrolysis and reducing free fatty acids and glycerol. The remaining VLDL molecules will then be removed from circulation or undergo further transformation will become lipoprotein lipase forming LDL [2]. When cholesterol synthesis in the liver decrease, it leads to cause suppression in the cholesterol synthesis process. When VLDL formation is reduced, the LDL formation is also dropped. These processes lead to serum LDL levels decreased. Babandi et al. (2018) demonstrated a similar pathway using in vivo study with the administration of flavonoids taken from Combretum micranthum. They found a significant decrease in serum LDL level in all treatment groups after giving flavonoid Combretum micranthum for two weeks [50]. Further, Sun et al. (2021) demonstrated a related pathway using in vivo study with the administration of flavonoids taken from Chrysanthemum. They found a significant decrease in serum LDL level in all treatment groups after six weeks of flavonoid administration of Chrysanthemum [51].

In contrast, Robianto et al. (2019) research demonstrated that Imperata cylindrica significantly caused inadequate effects to lower total cholesterol. Their study was focused on the effects of Imperata cylidrica as a contraceptive and its effectiveness in lowering total cholesterol. They employed female mice aged 8-12 weeks in the estrus phase to evaluate the vaginal swab cytology [27]. In the estrus phase, the vaginal mucosa undergoes structural changes that are affected by an increase in sex hormones such as FSH (Follicular Stimulating 
Hormone), LH (Lutheal hormone), progesterone, and estradiol [52,53]. These hormones cause effects by bonding with their respective receptors. The molecular mediators of estrogenic activity are alpha and beta estrogen receptors (ER $\alpha$ and ER $\beta)$ [54,55]. In addition, some nonsteroidal plant bioactive such as polyphenols in particular flavonoids can recognize Er $\alpha$ and $\operatorname{Er} \beta$ hormone receptors and have been considered as food phytoestrogens or endocrine disruptors [54]. At the same time, flavonoids can bind directly to $\operatorname{Er} \alpha$ and $\operatorname{Er} \beta$ [54,56]. The administration of flavonoids concomitantly with an increase in hormone sex such as estrogens lead to cause crosstalk between hormones and flavonoids. Subsequently, the flavonoid activity is inadequate.

However, some limitations still need to be noted in the current study. Future endeavors are valuable to evaluate each active compound of I. cylindrica and its role in reducing lipid levels. In addition, clinical trials are supposed to be established as requirements for using $I$. cylindrica in anti-hyperlipidemia treatment.

\section{Conclusions}

The eight studies of Imperata cylindrica we included in this paper reported beneficial effects on hyperlipidemia. However, the extent to which we can conclude the valuable effects of I. cylindrica as an anti-hyperlipidemic treatment is still restricted. The present study demonstrated that I. cylindrica caused the decrease in total levels of cholesterol, triglycerides, and LDL through in vivo studies and clinical trials. Further clinical studies are urgently required to provide adequate evidence on the application of $I$. cylindrica in medicine. Due to the limitations of current evidence, the need for better quality, either in vivo and randomized control trials (RCTs), to evaluate the efficacy of I. cylindrica is warranted.

\section{Funding}

This research was funded partly by Students' Parent Association (Ikatan Orang tua Mahasiswa/IOM) Fakultas Kedokteran Universitas Islam Malang and publication funding support provided by University of Islam Malang (UNISMA).

\section{Acknowledgments}

This research has no acknowledgment.

\section{Conflicts of Interest}

The authors declare no conflict of interest.

\section{References}

1. Hill, M.F.; Bordoni, B. Hyperlipidemia. StatPearls [Internet] 2021.

2. Pierce, J.; Agarwal, R.; Dhruva, Y.; Agarwal, A. Probability of Finding Significant Obstructive Coronary Artery Disease by Coronary Ct Angiography in Patients 70 and Below with Hyperlipidemia in A Outpatient Cardiology Private Practice. Journal of Cardiovascular Computed Tomography 2020, 14, https://doi.org/10.1016/j.jcct.2020.06.139.

3. Organization, W.H., Cardiovascular disease. http://www.who.int/cardiovascular_diseases/en/, 2017.

4. Franklin, B.A.; Myers, J.; Kokkinos, P. Importance of Lifestyle Modification on Cardiovascular Risk Reduction: Counseling Strategies To Maximize Patient Outcomes. Journal of Cardiopulmonary Rehabilitation and Prevention 2020, 40, 138-143, https://doi.org/10.1097/HCR.0000000000000496. 
5. Gill, P.K.; Dron, J.S.; Berberich, A.J.; Wang, J.; McIntyre, A.D.; Cao, H.; Hegele, R.A. Combined hyperlipidemia is genetically similar to isolated hypertriglyceridemia. Journal of Clinical Lipidology 2021, 15, 79-87, https://doi.org/10.1016/j.jacl.2020.11.006.

6. Lertwanichwattana, T.; Rangsin, R.; Sakboonyarat, B. Prevalence and associated factors of uncontrolled hyperlipidemia among Thai patients with diabetes and clinical atherosclerotic cardiovascular diseases: a cross-sectional study. BMC Research Notes 2021, 14, 1-8, https://doi.org/10.1186/s13104-021-05535-6.

7. Marques-Vidal, P. Comparison of lifestyle changes and pharmacological treatment on cardiovascular risk factors. Heart 2020, 106, 852-862, http://dx.doi.org/10.1136/heartjnl-2019-316252.

8. Cohen, B.G.; Goldman, D.P.; Ho, J.Y.; McFadden, D.L.; Ryan, M.S.; Tysinger, B. Improved survival for individuals with common chronic conditions in the Medicare population. Health Economics 2020, https://doi.org/10.1002/hec.4168.

9. Mach F, Baigent C, Catapano AL, Koskinas KC, Casula M, Badimon L, Chapman MJ, De Backer GG, Delgado V, Ference BA, Graham IM. 2019 ESC/EAS Guidelines for the Management of Dyslipidaemias: Lipid Modification to Reduce Cardiovascular Risk: The Task Force for the Management of Dyslipidaemias of the European Society of Cardiology (ESC) and European Atherosclerosis Society (EAS). European heart journal 2020, 41, 111-88, https://doi.org/10.1093/eurheartj/ehz826.

10. Organization, W.H. WHO Traditional Medicine Strategy: 2014-2023. World Health Organization. 2013.

11. Đurić, L.; Milanović, M.; Milošević, N.; Medic-Stojanoska, M.; Milic, N.; Maja. Herbs for Treatment of Hyperlipidemia: What is the Evidence? Current Topics in Nutraceutical Research 2021, 19, 146-156, https://doi.org/10.37290/ctnr2641-452X.19:146-156.

12. Khaerunnisa, S.; Aminah, N.S.; Kristanti, A.N.; Kuswarini, S.; Wungu, C.D.K.; Soetjipto, S.; Suhartati, S. Isolation and identification of a flavonoid compound and in vivo lipid-lowering properties of Imperata cylindrica. Biomed Rep 2020, 13, 38-38, https://doi.org/10.3892/br.2020.1345.

13. Cui, J.; Chao, L.I.; Jian, Y.; Xu, X.-d. Effects of imperatacylindrica polysaccharides on glucose and lipid metabolism in diabetic mice. Food Sci 2012, 33, 302-305.

14. Zarmi, S.Y.; Yetti, R.D.; Rivai, H. Review of Phytochemicals and Pharmacology of Medicinal Plants to Lower Blood Fat Levels. Int. Journal of Pharmaceutical Sciences and Medicine (IJPSM) 2021, https://doi.org/10.47760/ijpsm.2021.v06i03.001.

15. Jung, Y.-K.; Shin, D. Imperata cylindrica: A Review of Phytochemistry, Pharmacology, and Industrial Applications. Molecules 2021, 26, https://doi.org/10.3390/molecules26051454.

16. Nayim, P.; Mbaveng, A.T.; Ntyam, A.M.; Kuete, V. A botanical from the antiproliferative Cameroonian spice, Imperata cylindrica is safe at lower doses, as demonstrated by oral acute and sub-chronic toxicity screenings. BMC Complementary Medicine and Therapies 2020, 20, 1-2, https://doi.org/10.1186/s12906020-03064-6.

17. Abuga, I.; Sulaiman, S.F.; Wahab, R.A.; Ooi, K.L.; Rasad, M.S.B.A. Phytochemical constituents and antibacterial activities of 45 Malay traditional medicinal plants. Journal of Herbal Medicine 2021, https://doi.org/10.1016/j.hermed.2021.100496.

18. Razafindrakoto, Z.R.; Tombozara, N.; Donno, D.; Gamba, G.; Nalimanana, N.R.; Rakotondramanana, D.A.; Andrianjara, C.; Beccaro, G.L.; Ramanitrahasimbola, D. Antioxidant, analgesic, anti-inflammatory and antipyretic properties, and toxicity studies of the aerial parts of Imperata cylindrica (L.) Beauv. South African Journal of Botany 2021, 142, 222-229, https://doi.org/10.1016/j.sajb.2021.07.004.

19. Nago, R.D.T.; Nayim, P.; Mbaveng, A.T.; Mpetga, J.D.S.; Bitchagno, G.T.M.; Garandi, B.; Tane, P.; Lenta, B.N.; Sewald, N.; Tene, M.; Kuete, V.; Ngouela, A.S. Prenylated Flavonoids and C-15 Isoprenoid Analogues with Antibacterial Properties from the Whole Plant of Imperata cylindrica (L.) Raeusch (Gramineae). Molecules 2021, 26, https://doi.org/10.3390/molecules26164717.

20. Keshava, R.; Muniyappa, N.; Gope, R. Bioactivity Guided Fractionation and Elucidation of Anti-Cancer Properties of Imperata Cylindrica Leaf Extracts. Asian Pacific Journal of Cancer Prevention 2020, 21, $707-$ 714, https://doi.org/10.31557/APJCP.2020.21.3.707.

21. Olivo, S.A.; Macedo, L.G.; Gadotti, I.C.; Fuentes, J.; Stanton, T.; Magee, D.J. Scales to Assess the Quality of Randomized Controlled Trials: A Systematic Review. Physical Therapy 2008, 88, 156-175, https://doi.org/10.2522/ptj.20070147.

22. Peterson, J.; Welch, V.; Losos, M.; Tugwell, P.J. The Newcastle-Ottawa Scale (NOS) for Assessing the Quality of Nonrandomised Studies in Meta-Analyses. Ottawa: Ottawa Hospital Research Institute 2011, 12.

23. Higgins, J.P.T.; Altman, D.G.; Gøtzsche, P.C.; Jüni, P.; Moher, D.; Oxman, A.D.; Savović, J.; Schulz, K.F.; Weeks, L.; Sterne, J.A.C. The Cochrane Collaboration's tool for assessing risk of bias in randomised trials. BMJ 2011, 343, https://doi.org/10.1136/bmj.d5928.

24. Ma, L.-L.; Wang, Y.-Y.; Yang, Z.-H.; Huang, D.; Weng, H.; Zeng, X.-T. Methodological quality (risk of bias) assessment tools for primary and secondary medical studies: what are they and which is better? Military Medical Research 2020, 7, 1-1, https://doi.org/10.1186/s40779-020-00238-8.

25. Tran, L.; Tam, D.N.H.; Elshafay, A.; Dang, T.; Hirayama, K.; Huy, N.T. Quality assessment tools used in systematic reviews of in vitro studies: A systematic review. BMC Medical Research Methodology 2021, 21, 1-3, https://doi.org/10.1186/s12874-021-01295-w. 
26. Neni, A.; Mas Rizky, A.A.S.; Ghina Rahmadianti, M.; Almira, Z.; Rima Destya, T.; Yunisa, P.; Diah, D. Low Serum Cholesterol in Mice Pre-treated with Imperata cylindrica L. after Acute Olive Oil Gavage. KnE Life Sciences 2017, 3, 460-7, https://doi.org/10.18502/kls.v3i6.1155.

27. Robianto, S.; Syamsunarno, M.; Lubis, A.; Pricilia, M.; Anggraeni, N.; Ghozali, M. Ethanol extract of cogon grass root (Imperata cylindrica) potential as contraception agent by shortening estrus cycle in female mice. $J$ Veteriner 2019, 20, 196-201.

28. Khaerunnisa, S.; Kuswarini, S.; Suhartati, S.; Lukitasari, L.; Humairah, I.; Bn, R.A.; Gwenny, I.P. Sari Etanol, Etil Asetat Alang-Alang (Imperata cylindrica) terhadap Superoxide Dismutase (SOD). Indonesian Journal of Clinical Pathology and Medical Laboratory 2018, 20, 128-32.

29. Hsieh, Y.-L.; Yeh, Y.-H.; Lee, Y.-T.; Hsieh, C.-H. Ameliorative effect of Pracparatum mungo extract on high cholesterol diets in hamsters. Food \& Function 2014, 5, 149-157, https://doi.org/10.1039/C3FO60445D.

30. Ihsan, S.; Sonaru, F.; Satriani, H.; Wahyuni, I.; Ardianti, M. Efek antihiperlidemia obat tradisonal khas suku muna "lansau" berdasarkan parameter kadar LDL. Sainstech Farma 2018, 11, 7-11, https://doi.org/10.37277/sfj.v11i1.405.

31. Cho, Y.-G.; Jung, J.-H.; Kang, J.-H.; Kwon, J.S.; Yu, S.P.; Baik, T.G. Effect of a herbal extract powder (YY312) from Imperata cylindrica Beauvois, Citrus unshiu Markovich, and Evodia officinalis Dode on body fat mass in overweight adults: a 12-week, randomized, double-blind, placebo-controlled, parallel-group clinical trial. BMC Complementary and Alternative Medicine 2017, 17, https://doi.org/10.1186/s12906-017-1871-4.

32. Bogoriani, N.; Putra-Manuaba, I.; Suastika, K.; Wita, W. Cordyline Terminalis Kunth Leaves's Saponin Lowered Plasma Cholesterol and Bile Acids Levels by Increased the Excretion of Fecal Total Bile Acids and Cholesterol in Male Wistar Rats. European Journal of Biomedical and Pharmaceutical Sciences 2015; 2, 122-34.

33. Gu, M.; Kortner, T.M.; Penn, M.; Hansen, A.K.; Krogdahl, Å. Effects of dietary plant meal and soya-saponin supplementation on intestinal and hepatic lipid droplet accumulation and lipoprotein and sterol metabolism in Atlantic salmon (Salmo salar L.). British Journal of Nutrition 2014, 111, 432-444, https://doi.org/10.1017/S0007114513002717.

34. Ali, A.M.M.; Tawfik, M.F.; Hikal, M.S.; Tag El-Din, M.A. Hypocholesterolemic Effect Of Saponin Extracts In Experimental Animals. Arab Universities Journal of Agricultural Sciences 2018, 26, 2463-2478, https://doi.org/10.21608/ajs.2018.35613.

35. Wijaya, M.; Subandi. In Silico Analysis of Saponin Isolates from Mesocarp of Cucumber (Cucumic sativus L.) and Purple Eggplant (Solanum melongena L.) as Pancreatic Lipase Inhibitor. IOP Conference Series: Materials Science and Engineering 2020, 833, https://doi.org/10.1088/1757-899X/833/1/012053.

36. Ramchoun, M.; Khouya, T.; Harnafi, H.; Alem, C.; Benlyas, M.; Simmet, T.; Ouguerram, K.; Amrani, S. Effect of polyphenol, flavonoid, and saponin fractions from Thymus atlanticus on acute and chronic hyperlipidemia in mice. Future Journal of Pharmaceutical Sciences 2020, 6, 1-9, https://doi.org/10.1186/s43094-020-00097-z.

37. Monika, P.; Geetha, A. The modulating effect of Persea americana fruit extract on the level of expression of fatty acid synthase complex, lipoprotein lipase, fibroblast growth factor-21 and leptin - A biochemical study in rats subjected to experimental hyperlipidemia and obesity. Phytomedicine 2015, 22, 939-945, https://doi.org/10.1016/j.phymed.2015.07.001.

38. Bauer, J.E. Lipoprotein-mediated transport of dietary and synthesized lipids and lipid abnormalities of dogs and cats. Journal of the American Veterinary Medical Association 2004, 224, 668-675, https://doi.org/10.2460/javma.2004.224.668.

39. Wu, S.A.; Kersten, S.; Qi, L. Lipoprotein Lipase and Its Regulators: An Unfolding Story. Trends in Endocrinology \& Metabolism 2021, 32, 48-61, https://doi.org/10.1016/j.tem.2020.11.005.

40. Hoek-van den Hil, E.F.; Beekmann, K.; Keijer, J.; Hollman, P.C.H.; Rietjens, I.M.C.M.; van Schothorst, E.M. Interference of flavonoids with enzymatic assays for the determination of free fatty acid and triglyceride levels. Analytical and Bioanalytical Chemistry 2012, 402, 1389-1392, https://doi.org/10.1007/s00216-0115563-5.

41. Mazumder, T.; Mamun, I.P.; Zaman, M.S.; Islam, A.K.M.K.; Chowdhury, S.; Reza, M.S.; Hussain, M.S. Comparative lipid and uric acid suppressing properties of four common herbs in high fat-induced obese mice with their total phenolic and flavonoid index. Biochemistry and Biophysics Reports 2021, 26, https://doi.org/10.1016/j.bbrep.2021.100990.

42. Goedeke, L.; Rotllan, N.; Canfrán-Duque, A.; Aranda, J.F.; Ramírez, C.M.; Araldi, E.; Lin, C.-S.; Anderson, N.N.; Wagschal, A.; de Cabo, R.; Horton, J.D.; Lasunción, M.A.; Näär, A.M.; Suárez, Y.; FernándezHernando, C. MicroRNA-148a regulates LDL receptor and ABCA1 expression to control circulating lipoprotein levels. Nature Medicine 2015, 21, 1280-1289, https://doi.org/10.1038/nm.3949.

43. Pawlak, M.; Lefebvre, P.; Staels, B. Molecular mechanism of PPAR\&\#x3b1; action and its impact on lipid metabolism, inflammation and fibrosis in non-alcoholic fatty liver disease. Journal of Hepatology 2015, 62, 720-733, https://doi.org/10.1016/j.jhep.2014.10.039.

44. Mulvihill, E.E.; Allister, E.M.; Sutherland, B.G.; Telford, D.E.; Sawyez, C.G.; Edwards, J.Y.; Markle, J.M.; Hegele, R.A.; Huff, M.W. Receptor-null mice with diet-induced insulin resistance. Diabetes 2009, 58, 21982210 . 
45. Prince, P.S.M.; Kannan, N.K. Protective effect of rutin on lipids, lipoproteins, lipid metabolizing enzymes and glycoproteins in streptozotocin-induced diabetic rats. Journal of Pharmacy and Pharmacology 2006, 58, 1373-1383, https://doi.org/10.1211/jpp.58.10.0011.

46. Sung, J.H.; Lee, S.-J.; Park, K.H.; Moon, T.W. Isoflavones Inhibit 3-Hydroxy-3-methylglutaryl Coenzyme A Reductase in Vitro. Bioscience, Biotechnology, and Biochemistry 2004, 68, 428-432, https://doi.org/10.1271/bbb.68.428.

47. Kwon, E.-K.; Lee, D.-Y.; Lee, H.; Kim, D.-O.; Baek, N.-I.; Kim, Y.-E.; Kim, H.-Y. Flavonoids from the Buds of Rosa damascena Inhibit the Activity of 3-Hydroxy-3-methylglutaryl-coenzyme A Reductase and Angiotensin I-Converting Enzyme. Journal of Agricultural and Food Chemistry 2010, 58, 882-886, https://doi.org/10.1021/jf903515f.

48. Bao, L.; Hu, L.; Zhang, Y.; Wang, Y. Hypolipidemic effects of flavonoids extracted from Lomatogonium rotatum. Experimental and therapeutic medicine 2016, 11, 1417-1424, https://doi.org/10.3892/etm.2016.3038.

49. Abdel-Halim, S.; Ibrahim, M.; Abdel Mohsen, M.; Abou-Setta, L.; Sleem, A.; El-Missiry, M. The influence of the extraction method on polyphenols, flavonoids composition and anti-hyperlipidemic properties of papaya leaves (Carica papaya Linn.). Bulletin of the National Research Centre 2021, 45, 1-9, https://doi.org/10.1186/s42269-021-00548-4.

50. Babandi, A.; Musa, N.; MurtalaYa'u, H.M.Y.; Shehu, D.; Babagana, K.; Ibrahim, A. Lipid-Lowering Property of Flavonoid-Rich Portion of Combretum Micranthumon High Fat Diet Induced Hyperlipidemic Rats. International Journal of Bioscience, Biochemistry and Bioinformatics 2018, 9, 42-50, https://doi.org/10.17706/ijbbb.2019.9.1.42-50.

51. Sun, J.; Wang, Z.; Chen, L.; Sun, G. Hypolipidemic Effects and Preliminary Mechanism of Chrysanthemum Flavonoids, Its Main Components Luteolin and Luteoloside in Hyperlipidemia Rats. Antioxidants 2021, 10, https://doi.org/10.3390/antiox10081309.

52. Laksmi, D.N.D.I.; Trilaksana, I.G.N.B. The Change in External Genital and Estrogen Level of Bali Cattle During Estrus. Journal of Veterinary and Animal Sciences 2020, 3, 40-50, https://doi.org/10.24843/JVAS.2020.v03.i01.p05.

53. Thiyagarajan, D.K.; Basit, H.; Jeanmonod, R. Physiology, menstrual cycle. StatPearls [Internet] 2020.

54. Murray, C.M.; Orr, C.J. Hormonal Regulation of the Menstrual Cycle and Ovulation. Maternal-Fetal and Neonatal Endocrinology 2020, 159-167, https://doi.org/10.1016/B978-0-12-814823-5.00012-X.

55. Ugarte, R., FMO Interaction Energy between $17 \beta$-Estradiol, $17 \alpha$-Estradiol and Human Estrogen Receptor a. arXivpreprint arXiv:2012.10822 2020.

56. D’Arrigo, G.; Gianquinto, E.; Rossetti, G.; Cruciani, G.; Lorenzetti, S.; Spyrakis, F. Binding of Androgenand Estrogen-Like Flavonoids to Their Cognate (Non)Nuclear Receptors: A Comparison by Computational Prediction. Molecules 2021, 26, https://doi.org/10.3390/molecules26061613. 